O. Lagovska ${ }^{1}$, Dr. Sc. (Econ.), Prof., orcid.org/0000-0001-9517-0499, V. Ilin², Dr. Sc. (Econ.), Prof., orcid.org/0000-0002-4223-1865, M. Kotsupatriy ${ }^{3}$, Cand. Sc. (Econ.), Prof., orcid.org/0000-0001-5528-3210,

M. Ishchenko ${ }^{4}$, Dr. Sc. (Econ.), Prof., orcid.org/0000-0002-6820-9455,

L. Verbivska ${ }^{5}$, Cand. Sc. (Econ.), Assoc. Prof., orcid.org/0000-0002-2768-9157
1 - Zhytomyr Polytechnic State University, Zhytomyr, Ukraine

2 - University of the State Fiscal Service of Ukraine, Irpin, Ukraine, e-mail: villin2015@gmail.com

3 - Kyiv National Economic University named after Vadym Hetman, Kyiv, Ukraine

4 - Kryvyi Rih National University, Kryvyi Rih, Ukraine

5 - Yuriy Fedkovych Chernivtsi National University, Chernivtsi, Ukraine

\title{
PRIORITY DIRECTIONS OF TAX POLICY CHANGE IN THE INFORMATION SPHERE
}

Purpose. To substantiate the proposals about priority directions of tax policy change in the information sphere for various sectors of economy, in particular, mining industry. For development of proposals to analyze the current state of the information sphere, to identify and evaluate the possible risks from changes in taxation, to forecast tax rates using modern mathematical methods and algorithms, to set the limit for increasing the tax burden on experts in the information sector.

Methodology. The improved method of modeling interval time series was used for prognostication of volume of tax receipts from experts in the information sector and the volume of export of information services. The parameter of volume of export matches the requirements for applying the specified method. This parameter applies to flow variables. The use of the interval series method gives an opportunity to get sums of their levels, which is convenient for solving the task of forecasting. As the model of the so-called mathematical apparatus of forecasting, "Generalized AutoRegressive Conditional Heteroscedasticity" - UARUG (GARCH) was chosen, the Adaptive Rejection Metropolis Sampling (ARMS) was used. The use of ARMS makes provisions for the use of Hastings-Metropolis and adaptive rejection sampling (ARS) methods. The obtained results were approximated to construct analytical equations of predictive parameters over time.

Findings. A detailed analysis of the situation in the field of information services for various sectors of the economy, in particular, mining industry, was conducted. The risks of increasing the tax burden beyond certain boundary values were identified. The calculations of the forecast values of the volume of export of services and the amount of tax burden on the information sector up to 2025 were carried out. This made it possible to scientifically explain possible changes in the tax policy in the information sector. Suggestions for priority directions of tax policy change in the information sector for various sectors of economy, in particular, mining industry, were given.

Originality. The specific proposals for priority directions of tax policy change in the information sphere for various sectors of economy are developed and substantiated. The limit of possible increase in taxation on experts in the information sector was grounded and the value of this limit was calculated for the first time. The improved interval time series modeling method was used to forecast the volume of the single social security tax of the future periods and the volume of export of IT services for the first time. In contrast to traditional methods, which rely on existing forecasts, the polynomial approach reducing the relative error is proposed.

Practical value. The detailed recommendations on tax policy change in the field of information services for various sectors of the economy, in particular, the mining industry are given. The need for a change in tax policy, for individual entrepreneurs in particular, is pointed out. It is noted that the proposed changes should be implemented gradually, as transparently as possible and on the condition of careful monitoring in the industry. The analytically presented forecasting makes their practical application convenient.

Keywords: tax system, information services, individual entrepreneurs, tax benefits

Introduction. Today, the global economy has entered the digital stage of its development. A characteristic feature of this phase is the increase in the value of intangible assets in relation to tangible assets, even in industries such as mining, where the share of tangible assets still prevails. The main difference between this stage and the previous one, when the intensification of production was achieved by its automation by optimizing technological processes in the context of the workforce, is the transition from focusing on specialists to focusing on Chief Digital Officer (CDO). Sometimes the definition of Chief Digital Transformation Officer (CDTO) is also used in the scientific literature. The primary role of the CDTO is to transform an organization or team in their transformation from traditional business processes to digital. This points to the crucial role of digital technology, the importance and weight of a qualified manager in enhancing the efficiency of each sector of the country's economy, in particular, the mining industry. In these circumstances, the main task of tax policy is to promote

(C) Lagovska O., Ilin V., Kotsupatriy M., Ishchenko M., Verbivska L., 2020 the introduction of digital technologies, not to hamper them, to stimulate information professionals, and not to force them to leave the country.

Today it can be stated that the preferential taxation of the information sector of Ukraine, which was formed and has been working for more than twenty years, has created the conditions for intensive development of the modern information sphere of the Ukrainian economy. Information technology has taken one of the leading positions in the export-oriented areas of the economy. This began the stage of economic development of the country, characterized by a decrease in the share of exports of raw materials and an increase in the share of exports of services.

The country's government has indicated the need to change the tax policy in the information sector and increase its contribution to the country's budget. Therefore, it becomes crucial to determine how changes should be made and where the boundary for raising the tax burden on the information sector should be drawn.

Unsolved aspects of the problem. The question of tax policy change in the field, which is the driving force of changes in the 
economy of the country, the tax burden on its employees requires both an analysis of the current state of the industry, its achievements and prospects, as well as the risks associated with increasing the tax burden. The possibility of increasing the tax burden should take into account the globalization of the world economy in such cutting-edge industries as the information sector. Therefore, it is necessary to take into account not only the proportionality of taxes of the information industry and other industries in Ukraine, but also compare the size of taxation of information services in our country and in the leading countries of the world. The scientific community has not paid enough attention to this important issue.

The substantiation of the proposed changes to the taxation of the information sector requires the use of modern mathematical methods.

Assessing the possibility of replenishing the country's budget by increasing the tax burden on the industry, the effectiveness of levers of tax impact requires forecasting the growth of exports of information services, preventing a reduction in the tax base, and so on. This forecast should be the basis for making proposals for effective tax policy changes in the information sector.

Purpose. To substantiate proposals on priority directions of tax policy change in the information sector for various sectors of economy, in particular, mining industry. To develop proposals - to analyze the current state of the information sector, identify and assess the possible risks of changes in taxation, to predict the amount of taxation using modern mathematical methods and algorithms, to set limits for increasing the tax burden on employees in the information sector.

Materials and methods. The concept of "information sector" covers different areas of information activities and requires specialists in different fields, professionals who mostly have several professions, in particular, in mining, engineering. Like all over the world, such professionals are creating a new social and economic community. This community is extremely dynamic and mobile in every respect from the readiness to acquire new knowledge and skills to the change of place and direction of work. As the industry grows rapidly, it needs more experts and more jobs in various fields.

The information services sector is a general concept. For example, the mining industry works with large companies, R\&D centers, information laboratories as well as with professionals registered as Individual Entrepreneurs. Individual entrepreneurs are also heterogeneous. According to the accepted ranking, among them some are qualified as highly skilled workers and the most part as specialists of low qualification. It is this group that has the lowest demand of employers.

Therefore, for further analysis, let us determine the belonging of economic entities to the information sector of the economy under the Tax Code of Ukraine ("Transitional Provisions", subsection 2, item 26). The information sphere includes "Software Supply Operations (PP, author's abbreviation), and PP Operations" [1].

Specifically, the software includes: "the result of computer programming in the form of operating system, system, applied, entertaining and/or training computer program (hereinafter referred to as "CP"), their components, in the form of websites and/or online-services and access to them; instances (copies, samples) of the $\mathrm{CP}$, their parts, components in material and/or electronic form, including code(s) and/or links for downloading the $\mathrm{CP}$ and/or parts thereof, code(s) components for activation of $\mathrm{CP}$ or in any other form; any changes, updates, additions, complements and/or functional extension of the $\mathrm{CP}$, the right to receive such updates, changes, additions, complements within a certain period of time; cryptographic information security agents" [1].

The Ministry of Economy has pointed to the most promising sectors of the economy, which are growing at the fastest in relation to other sectors: information, agricultural, chemical and pharmaceutical industries.
The information sector turnover is showing a tendency for rapid growth. According to confirmed data, in the first half of 2019 , turnover increased by $30 \%$ (from $\$ 1.25$ billion in 2018) to $\$ 1.64$ billion. In 2019, industry taxes amounted to UAH 6.1 billion, which is a $30 \%$ increase from USD 4.73 billion in 2018 $[2,3]$.

Even today the Ukrainian information services industry is ranked first in Europe and, according to various sources, second or third among other branches of Ukraine in terms of exports. In 2019 , industry exports totaled $\$ 2.43$ billion. From 2018 growth was $15 \%$ (16\% of total exports of services in the country, estimated at $\$ 15.23$ billion) [3]. This indicates a steady increase in the export growth rate of the industry.

The analysis of Table 1, compiled by the authors according to $[2,3]$, indicates a significant share of high-tech exports in the total export of information services. In terms of investment in startups, Ukraine takes one of the first places due to the development of the information sphere. Investments in 2018 amounted to $\$ 290$ million [3].

There are more than 4000 IT companies in Ukraine, the number of employees in which increased from 184700 in 2018 to more than 200000 by the beginning of 2020 [2, 3]. Among the industry employees, the number of individual entrepreneurs (158 037) exceeds the number of legal entities (15 423) by more than 10 times. The number of the officially employed people in the legal entities of the industry is 59806 people. That is, it can be stated that individual entrepreneur is the main component among the specialists employed in the industry. Therefore, the analysis of tax changes in the industry should mostly take into account the individual entrepreneur.

IT companies (which also use individual entrepreneurs) are not only involved in testing software products, outsourcing, providing IT services, but also produce branding products such as Grammarly, GitLab, Template Monster, Viewdle and others.

This indicates the orientation of the information industry to the most productive areas of activity. These trends are also indicated by the leading ratio of export to import in the information sector (import in 2019 amounted to $\$ 495.8$ million) [3].

The orientation of the mining industry to the domestic information service provider in recent decades has become a clear example of this.

Many scientific works are devoted to the questions of taxation of information sphere. This issue was dealt with by native scientists, in particular, Lyashenko V. I., Vishnevsky O. S. [2], Diba M.I., Guerny Yu. O. [4], Mishchenko L. O. [5], Lutsik A. I., Sinyutka N. G. [6], Matveychuk L. O. [7], and others as well as by foreign experts such as Delaney T.K. [8], Adams A., Freedman J., Prassl J. [9], Oei S.-Y., Ring D. [10], Sun J., Lynch T. D. [11], Rekova N., Dolozina I., Zaitsev Y., Zamlynskyi V. [12], Nitsenko V., Mardani, A., Kuksa, I., Sudarkina L. [13], and others.

Over the last decades, using the suggestions made by scientists, the state tax policy in the information sector has been extremely favorable.

Currently, under the Tax Code, certain activities in this area have benefits or, in general, are tax-exempt. For example, till 1.01.2023, the supply of software products is exempted from

Table 1

Export of information services by type

\begin{tabular}{|l|c|c|}
\hline \multicolumn{1}{|c|}{ Type of service } & $\begin{array}{c}\text { Export } \\
\text { olume, } \\
\text { million USD }\end{array}$ & $\begin{array}{c}\text { Proportion of export } \\
\text { of information } \\
\text { services, \% }\end{array}$ \\
\hline Computer services & 1920.0 & 79.2 \\
\hline Information services & 395.5 & 16.3 \\
\hline Telecommunications services & 110.6 & 4.5 \\
\hline
\end{tabular}


VAT. An exception to this is the condition of exceeding the limit of the total value of the delivered software products of 1 million UAH in the last calendar year. In the case of deliveries by a company of the software products that is liable/non-taxable, the company is obliged to pay a compensation payment. Also, if the registration is canceled, the company must increase the single tax fee from 3 to $5 \%$ or switch from a simplified to a general tax payment scheme.

Being aware of the rapid pace of the IT sector development, the government has declared to reach its exports of $\$ 13$ billion a year by 2025 , get 650000 jobs in the industry, and bring the information sector's share of GDP to $10 \%$.

At the same time, in the amount of the country's budget for the year 2019, the total tax revenues of which amounted to UAH 799.776 billion, the IT sector taxes are quite small in relation to other industries. The country's budget did not reach the prescheduled targets. The country's government is working to increase general fund revenues and increase new sources of budget replenishment. Therefore, the government is tasked to improve the taxation system of the information sector of the economy.

Over the last decades, the topic of information taxation has been widely discussed at various levels. Representatives from associations, clusters and other specialized associations have repeatedly agreed on controversial tax policy issues with government officials. A compromise was reached between multivector processes - the development of the information sphere and the growth of tax revenues to the country's budget. There was also an understanding of the state assistance in infrastructure development and build-up and retention of the information sector's human resources. In particular, a compromise was reached on controversial issues in the field of professional education. However, new proposals for information sector taxation are being put forward by government officials.

Discussion about taxation of the information sector has intensified significantly in the scientific literature, among practitioners and in the society in connection with the initiatives of the Government of Ukraine on the introduction of a tax for the formation of the IT Creative Fund - "Human Capital Development Fund" and the implementation of Bill No. 2615 . The above mentioned bill proposes to introduce the concept of "start-up" into the Tax Code [1] as a "newly created business entity (an individual or legal person), which has not decided upon the form of taxation" and to implement a separate group of taxation of individual entrepreneurs for the "start-ups". This will increase the tax pressure on employees in the information sector. Concerning this initiative, the head of the State Tax Service stressed the need to introduce a fifth group of individual entrepreneur taxation, as, according to him, the existing system is being used in the information sector for tax evasion. The fact that the single tax (ST) is paid to the local budgets at the place of registration of the individual entrepreneur, and not to the budget of the country (section 1 of Article 10 [1]) complicates the attitude of government officials to such a taxation system as the individual entrepreneur.

The tax rate was proposed at $1 \%$ in 2020, but it should rise to $5 \%$ in 2024 . The new tax will be paid in addition to the $5 \%$ single tax and the single social security tax.

It is also planned to introduce a $1 \%$ tax on the IT Creative Foundation with a gradual increase of up to $5 \%$ in the year 2024. At present, the tax is comprised of $5 \%$ Single Tax (ST) and the single social security tax.

Thus, the individual entrepreneur's tax burden should increase by $3.5 \%$ in 2020 (1.5\% of the military levy $+1 \%$ of the single social security tax $+1 \%$ of the IT Creative Fund) and by the amount of over $12.5 \%$ in the year 2025. But this tax burden in the year 2025 is calculated only if the individual entrepreneur taxation system is not abolished for the information sector.

As, according to available data, most legally employed industry professionals are registered as individual entrepreneurs, the tax optimization is an important nationwide issue for them. Increasing the tax burden on individual entrepreneurs in the information sector, with the aim of increasing budget replenishment, may cause undesirable consequences. Unlike in other industries, an IT specialist can stop working in Ukraine and continue working elsewhere. So increasing tax burden can lead to the loss of the information sector. The fluctuation of the national currency exchange rate over the last year also complicates the situation. As certain information technology spheres like outsourcing, for instance, are directed to work exclusively for export, the remuneration of a certain number of employees is tied to the dollar exchange rate. The fall of the dollar exchange rate reduces the amount of payment for industry experts in UAH. Thus, it is necessary to take into consideration not only a single factor of the amount of stimulation of the industry workers, but the multicollinearity of the factors in their entire combination.

Therefore, a certain increase in the tax burden for individual entrepreneurs should be made with the increased monitoring of information sector indicators in real time. Consent for the tax increase has already been received from representatives of large companies, but a significant number of individual entrepreneurs have expressed their disagreement with this decision. 7177 industry experts were surveyed regarding the implementation of the individual entrepreneur group 5 [3]. $86 \%$ of the respondents opposed, $3 \%$ supported, $1 / 2$ voted in favor of reforming the tax system as a whole, $30 \%$ considered it advisable to be limited to the third group of individual entrepreneurs.

The introduction of IPbox proposed by the government for businesses focused on certain information services does not cause such resistance and has already been agreed with representatives of major associations.

According to [14], less than $29 \%$ of the number of online professionals are officially registered. Provided that online work is an additional source of income, only $21 \%$ are registered. This indicates that under current tax benefits, $3 / 4$ of experts work in the shadow economy. Almost half of the respondents $(45 \%)$ are convinced that they do not need to formally register their activity in government bodies (tax administration and others) in order to work on online platforms. Among workers for whom online work is the main type of income only $29 \%$ have officially registered their activities; among those who have other sources of income except the platform the number of registered is still smaller, $21 \%$ [3]. This indicates a significant shadowing of the sector.

Obviously, there is a limit to the increase in tax burden. The smaller the difference in individual entrepreneur taxation in Ukraine and other countries becomes, the more people will change their places of residence to get better and safer living conditions, better medicine, better roads and others as a bonus.

Nowadays for professionals with the experience less than a year, the monthly steady increase in the number of vacancies during 2017 - early 2018 has changed for the trend of a stable number of vacancies of around 450 per month. These jobs collect about ten times the number of responses, which is $10 \%$ of the total number of IT professional vacancies and $20 \%$ of the total number of responses. Large outsourcing companies either do not require low-skilled workers at all, or train them with a high dropout rate at all stages of training. The information technology companies where low-skilled workers are employed are not able to hire more than $20 \%$ of the total staff, as this requires additional involvement of experienced workers who must supervise their work. This indicates that the domestic information industry does not need even a portion of young professionals who graduate from educational institutions. Training of specialists for working abroad is not an urgent task for Ukraine. Therefore, these professionals are mainly outsourced. On the other hand, the focus of the information sector on outsourcing is not a positive indicator because it re- 
quires a steadily increasing number of low-paid specialists. Unlike, for example, India, Ukraine is unable to provide such a development model in the current demographic crisis. In 2019, Ukraine topped the list of the countries in terms of working-age population decline. According to the World Bank, the country loses $1.4 \%$ of its labor force as a percentage of the current year to the previous one. The emigration of the working-age population is a multiplier of slowing economic growth. Lack of labor force slows down economic growth, slow economic growth causes labor force outflow, which again slows economic growth.

Even with the government raising the issue of changing the tax burden on the sector, it has already caused some negative consequences. The analysis of changes in the capital investment index for information and telecommunications technologies shows that, despite the growth of this index in 2019, the rate of this growth is significantly lower compared to 2018 .

Today, the average monthly income of an information sector employee in Ukraine is approximately equivalent to $\$ 1.5$ thousand according to polls. This equates to $\$ 18000$, for a year. We have calculated the tax burden on information technology professionals provided they are registered, for example, in the state of California (USA) using information [15]. Of the amount of $\$ 18000$ earned, an expert in the US will have to pay $\$ 2026$. The tax paid by an expert will be $11.25 \%$ of the amount earned. The marginal tax rate indicates that additional income that exceeds $\$ 18000$ will be taxed at a different rate per year.

The estimated average tax rate of $11.25 \%$ for the state of California is already below the projected tax rate of $12.5 \%$ for the year 2024 in Ukraine. Obviously, this value of the tax rate goes beyond the boundaries that are dangerous for the information sector, in particular, and the country as a whole, when professionals, beginning from the most experienced ones, will be stimulated to emigrate, and IT companies will be stimulated to change the country of registration due to the tax policy.

The analysis of Table 2 shows that the minimum level of the single social security tax (characteristic of individual entrepreneur-3) increased by 3.42 times over the period from 01.01.2016 to 01.01.2020.

This, accordingly, increased the budget revenues from the individual entrepreneurs. Therefore, the Government's proposal to increase the single social security tax payment by introducing a rate of payment of this tax basing not on one but on two minimum wages is now considered inappropriate. Table 2 confirms the gradual increase in this tax over the last three years by 1.5 times, i.e. more than is currently proposed

Table 2

The single social security tax

\begin{tabular}{|c|c|c|c|c|}
\hline Time line & 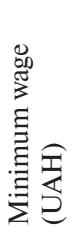 & 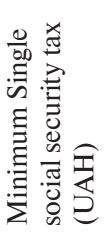 & 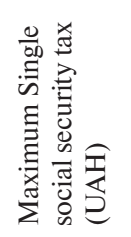 & 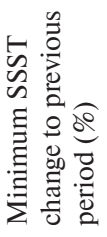 \\
\hline $01.01 .2016-30.04 .2016$ & 1378 & 303.16 & 7579.00 & -36.6 \\
\hline $01.05 .2016-30.11 .2016$ & 1450 & 319.00 & 7975.00 & +5.2 \\
\hline $01.12 .2016-31.12 .2016$ & 1600 & 352.00 & 8800.00 & +10.3 \\
\hline $01.01 .2017-30.04 .2017$ & 3200 & 704.00 & 8800.00 & +100.0 \\
\hline $01.05 .2017-30.11 .2017$ & 3200 & 704.00 & 9262.00 & +0.0 \\
\hline $01.12 .2017-31.12 .2017$ & 3200 & 704.00 & 9691.00 & +0.0 \\
\hline 01.01.2018-31.12.2018 & 3723 & 819.06 & 12285.90 & +16.3 \\
\hline 01.01.2019-31.12.2019 & 4173 & 918.06 & 13770.90 & +12.1 \\
\hline 01.01 .2020 - till now & 4723 & 1039.06 & 15585.90 & +13.2 \\
\hline
\end{tabular}

by the government. On the other hand, a clear increase in the minimum wage over time can lead to an unpredictable increase in the tax burden on industry professionals if the Government's proposals are fully implemented. PwC's research results show this, for instance.

Tax revenues to the budget of Ukraine from the information sphere are not only $5 \%$ of the single tax and the single social security tax paid by independent specialists. There are also payments to the budget from the income tax (at $18 \%$ rate) and the VAT (at $20 \%$ rate) made by IT companies.

The baseline data for comparing projected data with available tax revenue was the information from the Ministry of Digital Transformation of Ukraine for 2018 and the first half of 2019. Taxes paid by IT companies during the specified period are UAH 8.5 billion; UAH 7.5 billion was paid by individual entrepreneurs. Total payments to the budget for the specified period amounted to: UAH 11.5 billion, from legal entities and UAH 9.6 billion from the individual entrepreneurs. Total payments from the IT industry in the given period amounted to UAH 21 billion.

In addition to the mentioned scientific works, the officially tested forecasting methods were also analyzed. In particular, Higgins P., Zha T., Zhong K. [16] used Bayesian vector autoregression (BVAR) using the Sims and Zha approaches [16]. The Ministry of Economic Development, Trade and Agriculture [17], the Ministry of Finance [18], Financial and Economic Analysis Office of the Verkhovna Rada of Ukraine [19] mainly used the forecasting methods of the Institute for Economic and Political Studies, in which the iterative-analytical method was applied. These forecasts provide relevant results but for one to two years. We have been tasked with forecasting for the period up to 2025. Therefore, the interval time series modeling method was used to predict the factors of the information sector of the economy, in particular, the volume of export of services. The export volume parameter meets the necessary requirements for applying the specified method. It refers to flow variables. The use of the interval series method makes it possible to obtain sums of their levels, which is convenient to the prediction task.

We have chosen the model described in the scientific literature in detail, the so-called "Generalized autoregression with conditional heteroscedasticity" - UARUG (GARCH), using adaptive rejection metropolis sampling (ARMS) algorithm [20,21]. The use of the ARMS involves the use of Hastings-Metropolis and adaptive rejection sampling (ARS) methods. The improvement of the ARS method by the HastingsMetropolis method is due to the need to use log-density distributions. Creating a target log density using the rejection sampling algorithm optimizes the calculations, reducing the deviation of the predicted values. The distribution (q) of the parameter changes with each time interval. The algorithm used in the calculations is shown in Fig. 1.

Results. In forecasting the individual entrepreneur tax rate by 2025 , we have two options - a linear one, which is based on government forecasts, and a polynomial one, which we think is more appropriate.

The linear version of the forecast, as seen in Fig. 2, is characterized by a greater value of relative error, even when applied to prior periods. For future periods, as can be seen from Fig. 2, this error will increase significantly. But for estimating the economic indicators of the information sector, in particular for forecasting the minimum level of a single social security tax, the linear option is quite suitable.

The use of a linear approach to the simulation of the minimum single social security tax allows us to obtain the following algebraic equation using the approximation method

$$
990.06 x-302.16 y+13815.78=0 .
$$

The polynomial approach is shown in Fig. 3 .

In the polynomial modeling of the minimum SSST, the lowest value of the relative error (shown in Fig. 3) yielded the 


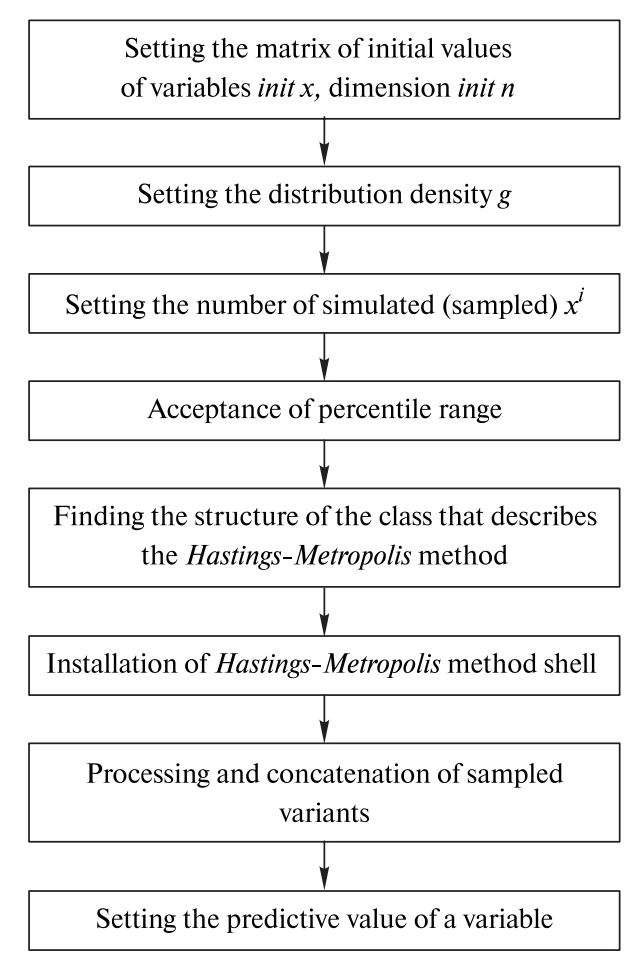

Fig. 1. Metropolis Sample Adaptive Deviation Algorithm (ARMS)

use of the fifth degree polynomial. The algebraic equation obtained in logarithmic form has the following form

$\ln \ln y=5.67+\frac{1}{2} \ln \ln x+\frac{1}{3} \ln \ln x+\frac{1}{4} \ln \ln x+\frac{1}{5} \ln \ln x$.

Based on the estimated number of annual job growth in the industry at 2000 levels by 2025 , with the condition of a steady growth, the projected level will be $\sim 300000$ jobs.

If the implementation of Group 5 for individual entrepreneur is not hard and has a number of benefits for employees,

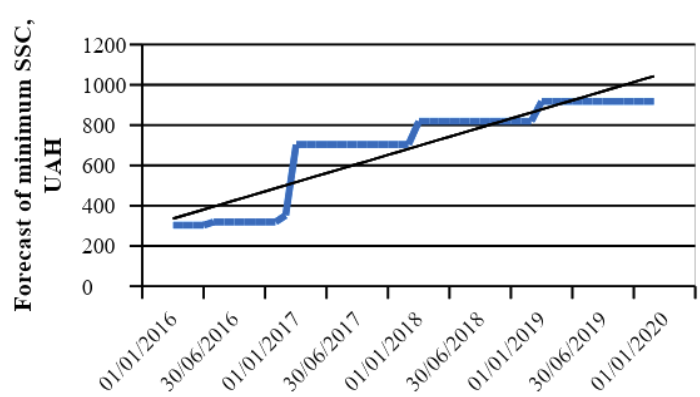

The time period

Fig. 2. Linear modeling of the minimum single social security tax

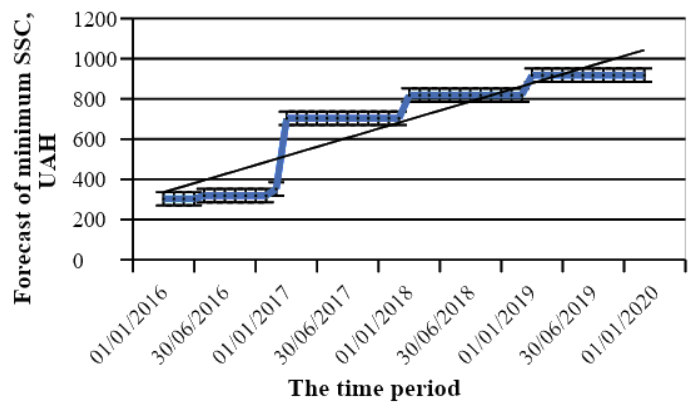

Fig. 3. Polynomial modeling of the minimum single social security $\operatorname{tax}(S S S T)$ there is a hope that it will not impede the growth of the information sector. The ability of specialists to have the choice of working under Group 3 or Group 5 rules of the individual entrepreneur taxation may, in our view, ease the transition to another tax regime.

The legal right of individual entrepreneur- 5 to work legally under contract and, even, not for one company, but for an unlimited number of them, will also be able to provide resiliency for the new tax system.

Assessment of the single social security tax for a new group of individual entrepreneurs on the basis of two minimum wages, as shown by a selective survey of industry experts, will lead to a dramatic increase in the level of taxation, and this can lead to negative consequences. We propose to leave the single social security tax assessment for the new individual entrepreneur group on the basis of one minimum wage, given the fact that the single social security for the $3^{\text {rd }}$ group of individual entrepreneurs increased three times in the last three years due to the increase in the minimum wage (Table 3 ).

We believe that in order to stimulate the information sector properly and create a competitive environment in the international market, the total tax burden should not exceed $10 \%$ with an increase of no more than $1 \%$ per year, as confirmed by studies conducted by the European Business Association (PwC).

According to the results of calculating the growth of the minimum SSST (Fig. 4), the amount of projected tax revenues from the individual entrepreneur- 3 of the information sector, provided there is no outflow of specialists from the country, will be increased by up to 5.2 times.

The estimated value of the export of information services to the year 2025 is shown in Fig. 5. This variant of the forecast is optimistic as the above mentioned risks of narrowing the tax base are not taken into account.

The algebraic equation describing the projected value of the volume of exports of information services also looks like a fifth degree polynomial, but at a time interval of 2020-2025 years with a satisfactory relative error (shown in Fig. 5), the analytical dependence can be obtained by approximation for formulation of mathematical expression, convenient in calculations

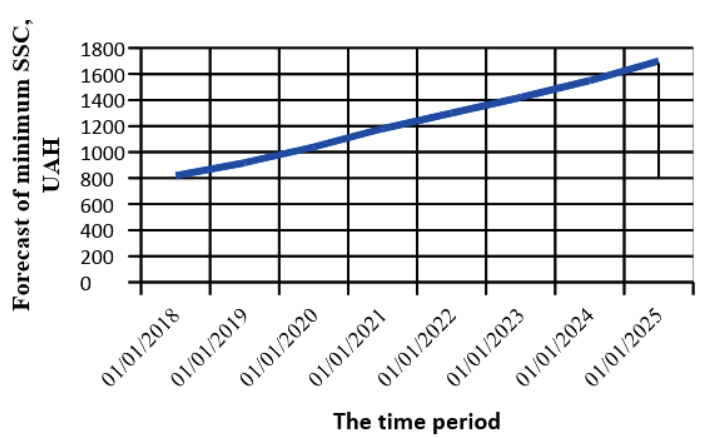

Fig. 4. Forecast of the minimum SSST in the following periods

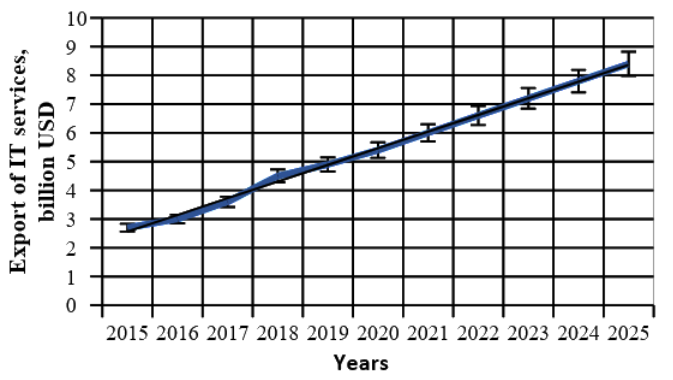

Fig. 5. Forecast of export volume of IT services 


$$
0.75 y-0.25 x+402.27=0
$$

If the government introduces a taxation of the information sector at a tax rate of $15 \%$ of the amount of export (which was also introduced by the government for discussion), budget revenues could amount to $\sim \$ 1.27$ billion. The forecast is in dollar terms because the long-term forecast of the national currency is beyond the scope of the scientific work presented. This projected budget replenishment is certainly higher than the figures above, but in our view, it is unattainable in view of the projected reduction in the tax base. Predicting the volume of tax base reductions in the presence of unspecified risks can only be estimated.

Only the estimated changes in the taxation of the information sector for the mining industry as a whole can be predicted. The crisis of the information sector will certainly reduce the pace of digital transformation of the mining industry, will lead to the need to attract foreign specialists, complicate the adaptation of modern information facilities to the realities of Ukrainian mining technologies. According to expert estimates, the transition to services of foreign information structures caused by the reduction of the Ukrainian information market may increase the cost of digital services from 9 to 12 times.

Conclusions. For over twenty years, the liberal tax regime for the supply of information services to various industries, in particular to the mining industry, has allowed the information sector to occupy one of the leading positions in shaping the country's export potential. Therefore, its change should be implemented in such a way that Ukraine does not lose the information sphere.

This article shows that the tax policy of the information sector should take into account not only the proportionality of taxes in other areas of the Ukrainian economy, but also taxation in other countries. This can prevent the information sector from shadowing and leaving the country. In addition to direct budget replenishment, tax policy should be aimed at increasing employment, increasing indirect taxes, and so on. That is, on the one hand, it is necessary to achieve an increase in budget revenues, on the other hand, not to reduce the growth rate of the industry, to prevent the transition to the shadow sphere or the emigration of a large number of individual entrepreneurs, who make up the largest share of employees in the information sector of workers. According to the studies, the work of one expert in the field of information creates employment in other sectors of the economy (three to five jobs). Therefore, the loss of the information sector will be accompanied by an abrupt loss of jobs in other sectors of the country's economy.

This allows us to make the following conclusions:

1. The tax policy of the information sphere demands changes. These changes should be developed for a certain period of time (5-10 years). The introduction of the changes requires maximum transparency and regularity. The process and effectiveness of introducing changes in the taxation of the information sector should be closely monitored to prevent possible harmful effects.

2. Forming tax policy prospects in the information sector for 10 years will allow for a soft adaptation to the planned changes for subjects of taxation, in particular, and the economic sector as a whole, without stimulating the shadowing of the sector and the mass departure of specialists and enterprises abroad.

3. It is advisable to retain the individual entrepreneur Group 3 for taxation of the information sector as a possible alternative to individual entrepreneur-5, since the introduction of individual entrepreneur- 3 in its time proved the efficiency of this form of taxation in the sector, contributed to its intensive development, entry of Ukrainian information products and services into the world market, tax volume growth of the information sector by $27-30 \%$ annually.
4. The introduction of the military levy $(1.5 \%)$ for the individual entrepreneur-5 is unconditional, meeting the needs of the country's defense and, accordingly, each of its citizens.

5 . We propose to charge the single social security tax in the short term on the basis of one and not two minimum wages with the reason that the above mentioned tax increased by three times in the last 3 years, and that the drastic increase in the tax burden which is connected with it may cause negative consequences.

6. In order to stimulate effective advanced development of the information sector, in order to prevent Ukraine's competitiveness in this area from decline, the total tax burden on the information sector should be no more than $10-11 \%$. To reach this level, it is proposed to introduce an annual rate of increase in the tax burden by $1 \%$.

7. In order to achieve the stated goals of creating the IT Creative Foundation, it is necessary to introduce both the relevant legislative framework of its functioning and transparent rules and tools for auditing its activities. But, first and foremost, the scientific substantiation of the fund's budget and the distribution of information sector allowances to it are required.

\section{References.}

1. Legislation of Ukraine (2010). Tax Code of Ukraine of 02.12.2010 No. 2755-VI. Vidomosti Verkhovnoi Rady Ukrainy, 13-14, 15-16, 17. Retrieved from https://zakon.rada.gov.ua/ laws/show/2755-17.

2. Liashenko, V. I., \& Vyshnevskyi, O.S. (2018). Digital Modernization of the Ukrainian Economy as a Breakthrough Opportunity: monograph. Kyiv: NAS of Ukraine, Institute of Industrial Economics. ISBN 978-966-02-8440-1.

3. IT Ukraine Association (2017). Ukrainian IT Industry: General Data and Expertise Level. Retrieved from http://itukraine. org.ua/news/infografika ukrayinska it industriya zagalni dani ta profesiynyy profil specialistiv

4. Dyba, M., \& Gernego, I. (2018). Digitalization of Economy: International Expirience and Possibilities of Development in Ukraine. Finansy Ukrainy, 7, 50-63.

5. Mishchenko, L. (2020). Improvement of the state budget of Ukraine projecting income. Efektyvna ekonomika, 4, 1-9. https://doi.org/10.32702/2307-2105-2020.4.51.

6. Synyutka, N. H., \& Lutsyk, A. I. (2018). Transformation of Fiscal Policy and Fiscal Space under Conditions of Digital Technologies Expansion. Accounting and Finance, 4(82), 108113.

7. Matveichuk, L.O. (2016). Information technologies and systems in public administration of taxation. Public Administration and Customs Administration, 1, 77-84.

8. Delaney, T. K. (2018). Taxing the Gig Economy. University of Pennsylvania Law Review, 166, 1-60, https://doi. org/10.2139/ssrn.2894394.

9. Adams, A., Freedman, J., \& Prassl, J. (2018). Rethinking legal taxonomies for the gig economy. Oxford Review of Economic Policy, 34(3), 475-494. https://doi.org/10.1093/oxrep/ gry006.

10. Oei, S.-Y., \& Ring, D. (2017). Tax Issues in the Gig Economy: Implications for Workers. Cambridge Handbook of the Sharing Economy, 343-356. https://doi.org/10.1017/9781108255882.026. 11. Lynch, T. D., Sun, J., \& Smith, R. W. (2017). Public budgeting in America. Irvine, California: Melving \& Leigh Publishers. Retrieved from https://www.amazon.com/PublicBudgeting-America-Sixth-Thomas/dp/0997308443.

12. Rekova, N., Dolozina, I., Nitsenko, V., Zaitsev, Y., \& Zamlynskyi, V. (2018). Budgetary revenue structure at central level of public administration in the federal countries. Administratie si Management Public, 30, 37-50. https://doi. org/10.24818/amp/2018.30-03.

13. Nitsenko, V., Mardani, A., Kuksa, I., \& Sudarkina, L. (2018). Additional opportunities of systematization the marketing research for resource conservation practice. Management Theory and Studies for Rural Business and Infrastructure 
Development, 40(3), 361-368. https://doi.org/10.15544/ mts.2018.34.

14. Aleksynska, M., Bastrakova, A., \& Kharchenko, N. (2018). Work on Digital Labour Platforms in Ukraine: Issues and Policy Perspectives. International Labor Organization. ISBN: 97892-2-030734-2.

15. Neuvoo (2020). Income Tax Calculator, California, USA. Find how much you salary is after tax. Retrieved from https:// neuvoo.com/taxcalculator $/$ ?iam $=\&$ uet calculate $=$ calculate $\&$ salary $=18000 \&$ from $=$ year\&region $=$ California.

16. Higgins, P., Zha, T., \& Zhong, K. (2016). Forecasting China's economic growth and inflation NBER working paper series. National bureau of economic research. Retrieved from https:// www.nber.org/papers/w22402.pdf.

17. Ministry for Development of Economy, Trade and Agriculture of Ukraine (2019). Forecast of economic and social development of Ukraine for 2020-2022. Retrieved from https://www. me.gov.ua/Documents/Detail?lang $=u k U A \& i d=9 \mathrm{cdcccd} 2-$ 10de-4073-bb63-09a94f88a741\&title=PrognozEkonomichno goISotsialnogoRozvitkuUkrainiNa2020-2022-Roki.

18. Ministry of Finance of Ukraine (2019). Information on fiscal risks and their potential impact on the state budget in 2019. Retrieved from https://mof.gov.ua/storage/files/39ae660ef0c ad97119c95ff41bfbf9e1.pdf.

19. Financial and Economic Analysis Office in the VRU (2020). Analysis of the forecasting methodology of main budgetforming taxes. Retrieved from https://feao.org.ua/products/ budgetoutvoruyutchi-podatky/.

20. Nitsenko, V., Mardani, A., Streimikis, J., Ishchenko, M., Chaikovsky, M., Stoyanova-Koval, S., \& Arutiunian, R. (2019). Automatic Information System of Risk Assessment for Agricultural Enterprises of Ukraine. Montenegrin Journal of Economics, 15(2), 139-152. https://doi.org/10.14254/18005845/2019.15-2.11.

21. Kuznietsova, N. V. (2017). Information Technologies for Clients' Database Analysis and Behaviour Forecasting. CEUR Workshop Proceeding, 2067, 56-62.

\section{Пріоритетні напрями зміни податкової політики в інформаційному секторі}

\section{О. А. Лаговська ${ }^{1}$, В. Ю. Ільїн ${ }^{2}$, М. М. Коиупатрий М. І. Іщенко ${ }^{4}$, Л. В. Вербівська ${ }^{5}$}

1 - Житомирський державний технологічний університет, м. Житомир, Україна

2 - Університет Державної Фіскальної Служби України, м. Ірпінь, Україна, e-mail: villin2015@gmail.com

3 - Київський національний економічний університет імені Вадима Гетьмана, м. Київ, Україна

4 - Криворізький національний університет, м. Кривий Ріг, Україна

5 - Чернівецький національний університет імені Юрія Федьковича, м. Чернівці, Україна

Мета. Обгрунтування пропозицій щодо пріоритетних напрямів зміни податкової політики в інформаційному секторі для різних галузей економіки, зокрема, гірничодобувної промисловості. Для розроблення пропозицій проведення аналізу наявного стану інформаційного сектору, виявлення та оцінювання можливих ризиків від змін в оподаткуванні, прогнозування показників обсягу оподаткування за використання сучасних математичних методів та алгоритмів, встановлення межі підвищення податкового навантаження на спеціалістів, які працюють в інформаційному секторі.

Методика. Для прогнозування обсягу податкових надходжень від спеціалістів, які працюють в інформаційному секторі, та обсягу експорту інформаційних послуг використано вдосконалений метод моделювання інтер- вальних часових рядів. Параметр обсягу експорту відповідає необхідним вимогам до застосування вказаного методу. Цей параметр відноситься до змінних потоку (flow variables). Використання методу інтервальних рядів дає можливість отримувати рішення їх рівнів, що $є$ зручним для поставленої задачі прогнозування. Як математичний апарат прогнозування обрана модель т. зв. «узагальненої авторегресії з умовною гетероскедастичністю» - УАРУГ (англ. GARCH), з використанням алгоритму адаптивного відхилення з дискретизацією за Метрополісом ARMS (англ. adaptive rejection Metropolis sampling). Застосування ARMS передбачає використання методів HastingsMetropolis i adaptive rejection sampling (ARS). Отриманні результати апроксимовані для побудови аналітичних рівнянь прогнозних параметрів від часу.

Результати. Проведено детальний аналіз стану сектору інформаційних послуг для різних галузей економіки, зокрема, гірничодобувної промисловості. Виявлені ризики збільшення податкового навантаження за певні межові значення. Проведені розрахунки прогнозних значень обсягу експорту послуг і обсягу податкового навантаження на інформаційну галузь до 2025 року. Це дозволило науково обгрунтувати можливі зміни в податковій політиці інформаційні сфери. Надані пропозиції щодо пріоритетних напрямів зміни податкової політики в інформаційному секторі для різних галузей економіки, зокрема, гірничодобувної промисловості.

Наукова новизна. Розроблені та обгрунтовані конкретні пропозиції щодо пріоритетних напрямів зміни податкової політики в інформаційному секторі для різних галузей економіки. Обгрунтована межа можливого збільшення обсягу оподаткування на спеціалістів, які працюють в інформаційній сфері, і вперше розраховане значення цієї межі. Для прогнозування обсягів надходження до бюджету країни єдиного соціального внеску наступних періодів і обсягів експорту IT послуг уперше використано метод моделювання інтервальних часових рядів. На відміну від традиційних методів, на які спираються існуючи прогнози, запропоновано поліноміальний підхід, що зменшує величину відносної похибки.

Практична значимість. Видані детальні рекомендації зі зміни податкової політики у сфері інформаційних послуг для різних галузей економіки, зокрема, гірничодобувної промисловості. Вказано на необхідність зміни податкової політики, зокрема, для фізичних осіб-підприємців. Відмічено, що запропоновані зміни треба запроваджувати поступово, максимально прозоро та за умови ретельного моніторингу в галузі. Представлення прогнозу в аналітичному вигляді робить зручним їх практичне застосування.

Ключові слова: система оподаткування, інформаційні послуги, фізичні особи-підприємці, податкові пільги

\section{Приоритетные направления изменения налоговой политики в информационном секторе}

\section{Е. А. Лаговская ${ }^{1}$, В. Ю. Ильин ${ }^{2}$, М. М. Коиупатрый ${ }^{3}$, Н. И. Ищенко ${ }^{4}$, Л. В. Вербивская}

1 - Житомирский государственный технологический университет, г. Житомир, Украина

2 - Университет Государственной Фискальной Службы Украины, г. Ирпень, Украина, e-mail: villin2015@gmail.com 3 - Киевский национальный экономический университет имени Вадима Гетьмана, г. Киев, Украина

4 - Криворожский национальный университет, г. Кривой Рог, Украина

5 - Черновицкий национальный университет имени Юрия Федьковича, г. Черновцы, Украина 
Цель. Обоснование предложений по приоритетным направлениям изменения налоговой политики в информационном секторе для различных отраслей экономики, в частности, горнодобывающей промышленности. Для разработки предложений - проведение анализа существующего положения в информационном секторе, выявление и оценка возможных рисков от изменений в налогообложении, прогноз показателей объема налогообложения при использовании современных математических методов и алгоритмов, установление предела повышения налоговой нагрузки на специалистов, работающих в информационном секторе.

Методика. Для прогнозирования объема налоговых поступлений от специалистов, работающих в информационном секторе, и объема экспорта информационных услуг использован усовершенствований метод моделирования интервальных временных рядов. Параметр объема экспорта соответствует необходимым требованиям к применению указанного метода. Этот параметр относится к переменным потока (flow variables). Использование метода интервальных рядов дает возможность получать результаты их уровней, что является удобным для решения поставленной задачи прогнозирования. Как математический аппарат прогнозирования выбрана модель т.н. «обобщенной авторегрессии с условной гетероскедастичностью» - УАРУГ (англ. GARCH), с использованием алгоритма адаптивного отклонения с дискретизацией по Метрополис ARMS (англ. Adaptive rejection Metropolis sampling). Применение ARMS предусматривает использование методов Hastings-Metropolis и adaptive rejection sampling (ARS). Полученные результаты аппроксимированы для построения аналитических уравнений прогнозируемых параметров от времени.

Результаты. Проведен детальный анализ в секторе информационных услуг для различных отраслей экономики, в частности, горнодобывающей промышленности. Выявлены риски увеличения налоговой нагрузки за определенные предельные ее значения. Проведены расчеты прогнозных значений объема экспорта услуг и объ- ема налоговой нагрузки на информационную отрасль в 2025 г. Это позволило научно обосновать возможные изменения в налоговой политике в информационном секторе. Даны предложения по приоритетным направлениям изменения налоговой политики в информационном секторе для различных отраслей экономики, в частности, горнодобывающей промышленности.

Научная новизна. Разработаны и обоснованы конкретные предложения по приоритетным направлениям изменения налоговой политики в информационном секторе для различных отраслей экономики. Обоснован предел возможного увеличения объема налогообложения на специалистов, работающих в информационной сфере, и впервые рассчитано значение этого предела. Для прогнозирования объемов поступления в бюджет страны единого социального взноса следующих периодов и объемов экспорта IT услуг впервые использован усовершенствованный метод моделирования интервальных временных рядов. В отличие от традиционных методов, на которые опираются существующие прогнозы, предложен полиномиальный подход, который уменьшает величину относительной погрешности.

Практическая значимость. Выданы детальные рекомендации по изменению налоговой политики в сфере информационных услуг для различных отраслей экономики, в частности, горнодобывающей промышленности. Указано на необходимость изменения налоговой политики, в частности, для физических лиц-предпринимателей. Отмечено, что предложенные изменения надо вводить постепенно, максимально прозрачно и при условии тщательного мониторинга в отрасли. Представление прогноза в аналитическом виде делает удобным их практическое применение.

Ключевые слова: система налогообложения, информационные услуги, физические лица-предприниматели, налоговые льготы

Recommended for publication by I. V. Hanzhurenko, Doctor of Economic Sciences. The manuscript was submitted 15.10.19. 